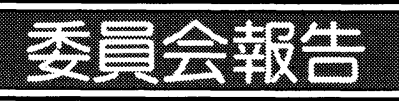

\title{
河口部の水理現象と関連する諸問題
}

\section{HYDRAULIC PHENOMENA NEAR THE RIVER MOUTH AND THEIR RELATED PROBLEMS}

\author{
土木学会水理委員会河口部の水理現象小委員会* \\ By Task Committee on Hydraulics near the River Mouth \\ in the Committee on Hydraulics and Hydraulic Engineering, JSCE
}

\section{1. まえがき}

河口部は河川と海岸の接点として, 河川流と潮汐, 波 および海浜流の作用を受け，そこで生じている水理現象 はきわめて多様で複雑な様相を呈する，一方において， 河口部の利用や保全あるいは河口処理は工学的に重要な 課題であり，人間生活と密接なかかわりを有している. 河口部の水理現象に関しては，河道内外の流れや波浪， 土砂の移動と地形変化, あるいはそれらに及ぼす河口構 造物の影響等, 種々の角度から多くの調査, 研究がなさ れてきた. しかしながら現象の複雑さと問題の多様性の ために, 総合的な観点からの河口部水理現象の把握は必 ずしも十分ではなく, 基礎研究の成果を実際の河口問題 の解決に適用し得るほどの一般化もなされているとはい えない.

このような認識のもとに土木学会水理委員会は, 関連 する既往の研究成果を調查再検討するとともに，総合的 な視点に立って河口部の水理現象の究明を推進するため に, 水理学, 河川工学, 海岸工学の研究者の参加を得て, 昭和 57 年 2 月に「河口部の水理現象研究小委員会」を 設置した. 以来, 本研究小委員会は, 次の 4 項目に関す る調査研究を進め, 昭和 57,58 年度段階までの研究成 果を取りまとめた。

（1） 河口周辺の流れと波

(2) 河口部の地形変化

（3）河口処理工法とその影響

（4）河口部の調查

報告書の印刷は諸般の事情により遅れているが, 近く

\footnotetext{
* 土木学会水理委員会河口部の水理現象小委員会
} ( 个160 新宿区四ツ谷 1 丁目無番地)
水理委員会に提出される予定である．本文は報告書を論 文集用にまとめ直したものであり，紙数の制約により内 容を大幅に圧縮せざるを得なかった。このため記述が不 十分な箇所も多々あろうが, 今後の研究の一層の発展の 一助となれば幸いである.

本研究小委員会の構成は下記のとおりである（*印は 委員兼幹事).

\section{委員長 : 堀川清司 (東京大学)}

河口周辺の流れと波分科会：首藤伸夫(東北大学), 玉井信行(東 京大学), 福岡捷二* (建設省)

河口部の地形変化分科会 : 鹿島遼一 (電力中央研究所), 沢本 正樹 (東北大学), 土屋義人 (京都大学), 野田英明 (鳥取 大学), 渡辺 晃* (東京大学)

河口処理工法とその影響分科会: 椹木 亨 (大阪大学), 須賀 堯三 (宇都宮大学), 鮏川 登* (早稲田大学), 田中則夫 (運 輸省), 橋本 宏 (建設省)

河口部の調査分科会：白波瀬正道(建設省), 土屋 進(建設省), 服部昌太郎* (中央大学), 山本晃一 (建設省), 吉田静男 (北 海道大学)

\section{2. 河口周辺の流れと波}

\section{（1） 河口部の流れ}

a ）河口部の流れの要因

河口部での流れを支配する要因は，運動を発生させる 営力, 場の境界としての地形, 河水海水間の密度差の 3 つであり，これらの因子は相互に影響し合う．河川流の 営力は重力であるが, 運動の大きな変化は降水量の増減 による. 沿岸海域での水運動は, 海流, 潮流, 波浪, 海 浜流等により生じる，地形は流れに大きな影響を及ぼす とともに，流れによって変化する．河口部ではさらに, 陸水亡海水の塩分や水温の相違や浮遊物質の濃度分布に 
起因する密度差が，流れの構造，特に鉛直構造に大きな 影響を与える.

b ） 河口部の範囲

狭義の河口部としては，波浪の到達末端あるいは 1 潮 汐時の海水到達点を上流端とし, 河川流の慣性が有意な 点あるいは密度フロント形成地点を下流端として定義で きる。これに対し広義には，感潮域上流端から海側で淡 水の存在が認められなくなる範囲までが河口部と定義さ れ, 狭義の河口部の範囲に比しその変動幅は小さい.

\section{（2）河口密度流}

a ）河口部における流況の分類

Hansen $\cdot$ Rattray $^{11}$ は，水底と水面の相対塩分濃度差 および周期平均潮流流速之断面平均淡水流速の比によ り，河口部の流況を 4 種に分類し，塩分輸送に及ぼす移 流と拡散の相対的重要性を論じた。一方, 須賀 ${ }^{2}{ }^{2}$ は, 水 面と水底の塩素イオン濃度の比 $C_{S} / C_{B}$ を用いて, 日本 の河川下流部における混合型を, 弱混合 $\left(C_{S} / C_{B}<0.1\right)$, 緩混合 $\left(0.1<C_{S} / C_{B}<0.5\right)$, 強混合 $\left(0.5<C_{S} / C_{B}\right)$ に 分類整理し，図一1 を得た。

b ) 土砂の凝集化現象亡輸送特性

(1) フロック形成のメカニズム ${ }^{3), 4)}$

粘土やシルトなどの微粒分は, 河口部で塩分に出会う と電気化学的反応により凝集しフロックを形成する. フ ロック形成に影響する衝突確率にはブラウン運動と流れ の局所的速度勾配が関与し，フロック化が進むにつれて 速度勾配の効果が卓越するようになる.

(2) フロックの力学的性質

フロックは沈殿して界面を生じるが，沈殿層厚を $h$, 圧密沈下後の最終厚を $h_{\infty}$, 経過時間を $t$ とすると,

$\left(h / h_{\infty}\right)-1=\alpha / t$

が成立する. ただし沈降前期と後期で $\alpha$ の值が異なる. San Francisco 湾の浮泥の場合, 最終的なフロック間の 空隙率は 0.44 , 密度は $1.19 \mathrm{~g} / \mathrm{cm}^{3}$ であった。

塩水中に浮遊させた San Francisco 湾の底泥はビン ガム流体の特性を示し, ビンガム降伏值 $Y\left(\mathrm{~N} / \mathrm{m}^{2}\right)$ と 浮遊粒子濃度 $C(\mathrm{~g} / \mathrm{l})$ の関係は次式で与えられた。

$Y=5.9 \times 10^{-3} \mathrm{C}$.

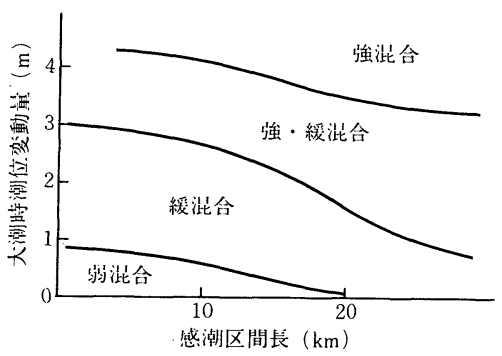

图一1＼cjkstart河川下流部の混合形態の分類 ${ }^{2}$
Thames 河ロにおけるフロックの沈降速度の現地観 測 ${ }^{5}$ によれば, 沈降速度 $w_{s}(\mathrm{~mm} / \mathrm{s})$ と体積濃度 $C_{v}(\mathrm{ppm})$ の間には,

小潮時 : $w_{s}=2 \times 10^{-5} C_{v}^{2}$, 大潮時 : $w_{s}=2 \times 10^{-3} C_{v}$

の関係があり，塩分濃度の影響は顕著でない．

Einstein・Krone ${ }^{3)}$ は流水中での浮遊粒子の挙動に関 する実験を行った. 図一2 は流水中でのフロックの沈降 に伴う粒子濃度の変化を示す. 図中破線は水路中に格子 を挿入したときの結果で，格子背後の乱れにより局所的 速度勾配が増大し堆積率が増加する様子が示されてい る.

底泥の流送に関して, 大坪 ${ }^{6}$ は 2 つの限界掃流力を定 義した，底泥粒子が巻き上がり始める流送限界 $\tau_{c 1}$ と, 河床面が破壊され大量の底泥流送が生じる破壊限界 $\tau_{c 2}$ であり，ビンガム降伏值 $Y\left(\mathrm{~N} / \mathrm{m}^{2}\right)$ との間に，

$$
\tau_{c 1}=0.27 Y^{0.56}, \tau_{c 2}=0.79 Y^{0.94} \text {. }
$$

なる関係が得られている。

(3) 現地観測により得られている特性

San Francisco 湾に連なる Napa 川の河口部での放射 性同位体を用いた観測 4 によれば，流れにほぼ直角に突 出した栈橋の両側で堆積が目立った。これは後流域の乱 れにより速度勾配が増大し，フロック形成が促進された ことによると考えられる。

Gordon $^{7)}$ は，潮流中での流速測定結果に基づき，平 均流速が同一であっても, 底面応力と乱れエネルギーは 減速期には加速期の 2 倍に達し, これが底質輸送に大き く影響すると述べている．多摩川河口における観測例8) では，下げ潮時に浮遊砂濃度が大きくなっている.

c）水理模型による浮遊土砂問題へのアプローチ

Thames 川の河口堰建設計画に際しては, 河道約 100 $\mathrm{km}$ を対象とした移動床実験が行われた ${ }^{5)}$. プラスチッ ク粒子を底質材料として用いて, 浚渫後の地形変化から 時間尺度を求めたのち河口堰を導入し, 最適位置の選定 を行った．塩分の存在下の凝集過程を含む水理実験も， Lepetit ら9)により行われている.

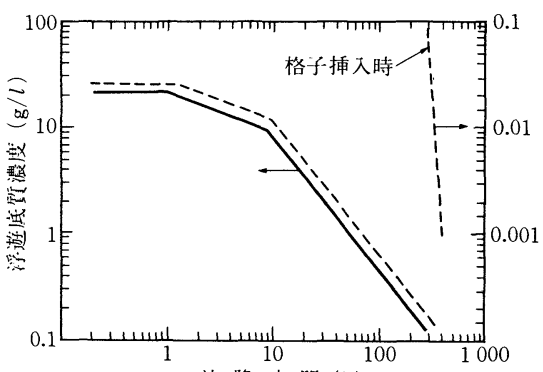

沈降時間 (h)

図一2 流水中でのフロックの沈降 ${ }^{3)}$ 
d）数学モデルによるアプローチ

(1) 粘着性粒子の輸送モデル

上記の Thames 河口堰計画においては数学モデルに よる検討も行われた. 断面を長方形で近似した 2 層モデ ルで, 各層の速度と濃度は一様として扱い, 鉛直拡散係 数 $\epsilon$ は摩擦速度 $U_{*}$ と全水深 $h$ を用いて $\epsilon=E U_{*} h$ と 仮定した（定数 $E$ の最適值は 0.0067). シルトの限界 掃流力を塩分濃度に応じて増加する形におくことによ り，上下層の浮遊土砂濃度の縦断方向変化に対して実測 値との満足できる合致を得ている.

なお，簡単な解析モデルにより堆積土砂量の推定を試 みたものとしては, Harrison・Owen ${ }^{10)}$ の論文がある.

(2) 河口部における水質指標の輸送モデル

強混合の条件に対しては一次元モデルが用いられるこ とが多いが，緩混合の場合には鉛直二次元モデルを用い た扱いがなされている11),12). また，水平面内の分布を論 じるためには水平二次元モデルが用いられる：いずれに しても，拡散係数等の係数值の設定法が 1 つの課題であ る.

\section{（3）河口流出}

a) 河口条件

河口条件は河口を明確に定義づけるうえで重要であ り，河口条件が与えられなければ，河口を流出する河川 水の内部跳水の発生位置や塩水くさびの侵入形状等を精 度よく算定することも不可能である。

河口条件に関する研究は Stommel ・ F armer ${ }^{13)}$ に始ま り，内部フルード数が 1 となる支配断面が河口に生じる ことが定常漸変流の仮定のもとに理論的に導かれた．当 初はこの条件が河口密度流では一般的に成立すると考え られていたが, 現地観測および室内実験の結果から，こ の条件が成立しない場合もあることが見出されてき $た^{14), 15)}$. 福岡ら ${ }^{16)}$ は, 粘性や浮力に加えて流線の曲がり の影響をも考慮した解析を行い, 支配断面の位置とそこ での淡水深や内部フルード数の決定法を示した. $180^{\circ}$ に広がる流出形態については, Hele-Shaw 近似を適用 することにより，河口での内部フルード数 $F_{i 0}$ に対する 次式を得ている.

$$
F_{i 0}=c\left(R_{e} \cdot h_{c} / B_{0}\right)^{3 / 8}
$$

ただし， $c$ は幾何学的形状に依存する係数, $R_{e}=Q_{1} /$ $\left(\nu B_{0}\right), h_{c} / B_{0}=\left\{Q_{1}^{2} /\left(\varepsilon g B_{0}\right)\right\}^{1 / 3}, Q_{1}$ は淡水流量, $B_{0}$ は河 口幅, $\varepsilon$ は相対密度差である.

b ）海に流出する河川水の広がり

(1) 平水, 洪水, 渴水時の流出形態

柏村・吉田 ${ }^{15), 17}$ は, 河口流出実験を系統的に行い, 淡 · 塩水の密度差, 淡水の流量および水路幅の違いにより, 河口流出形態がゼのように変化するかを検討し, 流出形 態を放射状に大きく広がる A 型から表面密度噴流の形状
に類似する $\mathrm{E}$ 型までの 5 種類に分類した。このような各 種流出形態は実河川においても観測されており, 同一河 川であっても, 渴水時には浮力効果が卓越して A 型が生 じ, 洪水時には $\mathrm{E}$ 型が現われやすい等, さまざまに変化 することがわかっている.

柏村らは, 流出形態の夕イプが, $2 つ$ 無次元量の関 係亡して, 次式で規定されるとしているが, 実河川の現 象は必ずしも説明できていない.

$$
\theta \cdot R_{b}^{0.137}=\text { const. }
$$

ここで, $\theta=(\varepsilon g \nu)^{1 / 3} / U_{0}, R_{b}=U_{0} B_{0} / \nu, U_{0}$ は河口での 淡水平均流速である. 一方福岡ら ${ }^{16), 18)}$ は, 水深幅比 $A_{R}$ $=h_{c} / B_{0}$ とレイノルズ数 $R_{e}=U_{0} h_{c} / \nu$ を用い, 両者が小 さいときには $\mathrm{A}$ 型が現われ， $R_{e}$ が小さいときには $A_{R}$ が小さいほど広がりが大きいが，実河川のように $R_{e}$ が 大きい場合には $A_{R}$ の効果は小さいことを見出してい る.

また，河口を出て一度広がった河川水が途中で一時縮 小し，再び広がるという複雑な挙動を示す場合があ $3^{16), 18), 199}$.

\section{(2) 潮汐や波浪による河口流出の変化}

柏村・吉田 ${ }^{20}$ は, 潮汐による河口流出形態の変化を実 験により調べた.潮位差が小さいときは常に順流である. 潮位差が大きい場合の河川水の広がり形状は，満潮時に 放射状，落潮時に噴流状で，干潮時には河川水の流速が 減じ，漲潮時には逆流を生じる..このため河川水は間欠 的に流出し，沖でパフ状になって広がる.

高潮に伴う河口付近の流れの変化については，中村 ${ }^{21)}$ により実験が行われている．また，波による河口流出の 変化が Wright ら ${ }^{221}$ により観測され，砕波や沿岸砂州の 影響が大きいことが示された。潮汐・高潮・波浪の影響 については，なお一層の研究が望まれる.

c）河口での河川水と海水との混合

Wright ・ Coleman ${ }^{23)}$ は, Mississippi 川河口での 5 年 間にわたる現地観測から, 河川流と潮位の変化に伴い, 河口域の流れや底面形状が著しく変化することを示し た. 河川水と海水の混合の程度は特に流量に左右される. また，この混合には河口域に形成された浅瀬の影響も大 きい. 浅瀬の上流側斜面上では乱れによる混合が著しく 流れはすべて沖向きであり, 浅瀬頂部の浅水域では混合 は同様に活発だが流速は急速に減少し, 下流側斜面上で は内部跳水が生じ上下層で流向が逆になり，さらに沖側 の浅瀬末端部では安定な成層状態となって外海の流れに よる混合が起きている.

須賀 ${ }^{24)}$ は河口流出の実測を行い，河口付近に形成され る内部ジャンプ渦が連行や混合ならびに河川水の流動状 況と密接に関係することを示した. 吉田 ${ }^{25}$ は石狩川河口 で同様な大規模な界面破壊の状況を観測している. 
(1) 河口付近の密度フロント現象

河口付近に形成される密度フロントについては，かな り以前から観測や研究がなされてきたが，最近ではリ モートセンシングデータの活用が目立っている ${ }^{26)}$.

\section{（4）河口部周辺の波の挙動}

a ）流れの中での波の変形

かつては，流れにのった波の波高は，波エネルギーが 群速度（流れの流速と相対群速度のベクトル和）で輸送 されるとして計算されていた。この扱いは，ラディエー ション応力が流れに対してなす仕事が評価されていない ので，誤りである．群速度で運ばれるのは波エネルギー ではなく，それを相対周波数で割った波作用量であると して扱う必要がある.

流れの時間的空間的変化が緩やかであると仮定して, 平均量に対する基本方程式群が導かれている ${ }^{27), 28)}$. 未知 量は, 波高, 平均水位, および波数ベクトルと平均流速 ベクトルの各 2 成分の計 6 個であり, 波数, 質量, 運動量, 波作用量の各保存則が 6 個の方程式を与える.

波と流れの共存場で最も単純な条件は，一様流に波が

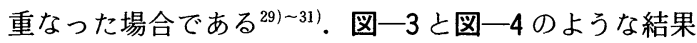
が得られている.ただし， $L$ は波長， $H$ は波高， $h$ は 実水深であり, 添字 0 は流れのない深海での量を意味す
が平面分布をもつ流れが存在する場合の問題も解かれて いる32).

現実の河口部付近の流れの流速分布は鉛直方向に一様 ではなく, 密度効果が影著な場合には上層と下層で流れ の向きが異なることもまれではない。こうした流速の 鉛直方向勾配の効果を考慮した扱いも多数なされてい $3^{33) \sim 388}$.

浅い水域で波高の大きい波では, 非線形効果が無視で きなくなる．一様流中の有限振幅波に対する計算がなさ れており ${ }^{39)}$-42), 実験とも比較されている. 流速分布が 一様でない場合の有限振幅波の変形に対する扱いもなさ れているが33), さらに研究を進める必要があろう.

また，一般的な平面の場での波と流れの干渉の問題に 対しても研究がなされている ${ }^{28,433,44)}$. この場合には, 数值計算により波と流れに対する方程式を交互に解くこ とになる。

b ) 波・流れ共存時の底面摩擦

定常流と波が共存している場合の底面摩擦は, 波の減 衰や海浜流の流速場を求めたり, 底質移動の問題を論じ る際に重要である. 定常流における壁面乱流の古典的モ デルにならい, 渦動粘性係数を壁からの距離と摩擦速度 の関数と仮定し,非定常境界層方程式を解く方法により,
る. また図中の数值は, 定常流の線流量 $q$ を流 れのない深海での波速 $c_{0}$ と波長 $L_{0}$ で無次元化 した $q^{*}=q / c_{0} L_{0}$ の值である. 順方向の流れで あれば波長が伸び波高は減少し, 逆行すると波長 は短くなり波高が増大する．鉛直方向には一様だ

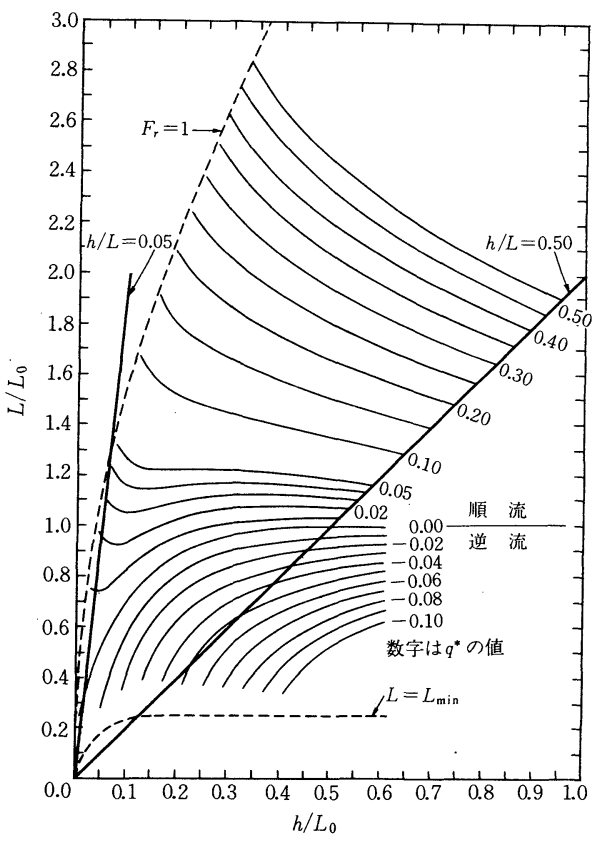

図一－样流中の波長変化 ${ }^{31}$

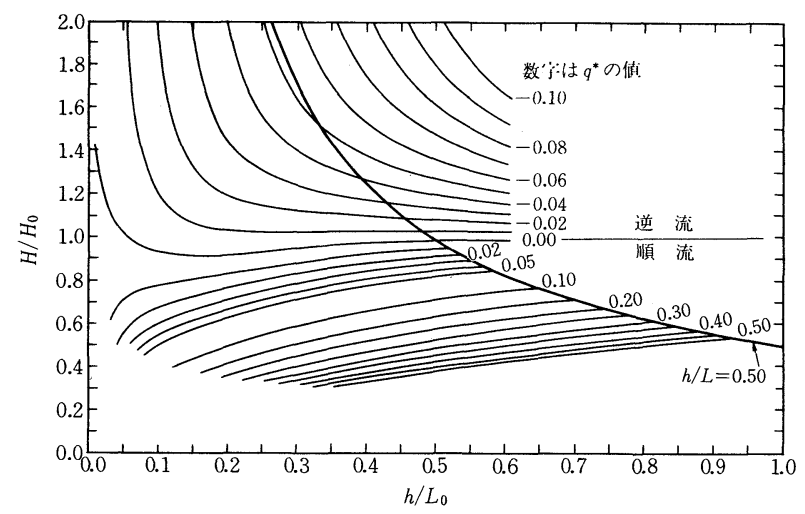

図一－様流中の波高変化 ${ }^{31)}$

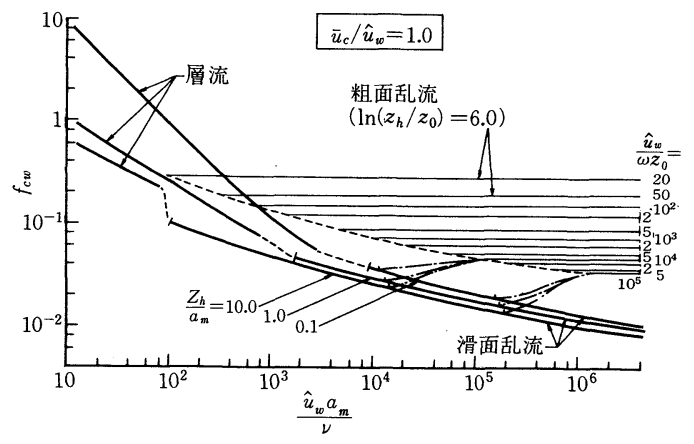

図一5 波・流れ共存場の摩擦係数 ${ }^{47)}$ 


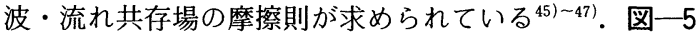
は, 田中・首藤 ${ }^{47)} に よ り$ 求められた摩擦則の結果の一例 であり, 定常流の平均流速 $\bar{u}_{c}$ と境界層外縁での波動流 速振幅 $\hat{u}_{w}$ が等しい場合に相当する.なお図中で， $f_{c w}$ は $\hat{u}_{w}$ と底面での最大摩擦応力 $\tau_{\max }$ を用いて $\tau_{\max }=(\rho / 2)$ $f_{c w} \hat{u}_{w}^{2}$ として定義される摩擦係数であり， $a_{m}$ は底面で の水粒子軌道振幅， $\omega$ は波動の角周波数， $\nu$ は動粘性係 数， $z_{h}$ は水深， $z_{0}$ は粗度長である. 図中の一点鎖線は 滑面乱流から粗面乱流への遷移域のものでやや任意性が ある. 境界層の遷移条件をも含め, 実験的な研究もさら に進める必要がある。

\section{3. 河口部の地形変化}

\section{（1）海岸の漂砂}

河口付近は河川流と波浪や海浜流の作用下にあり，そ こでの底質移動や地形変化は複雑である．河口部に特有 の地形変化について述べる前に，海岸での漂砂について 略述する。

波動場にある砂粒子は非定常外力を受けるが，移動限 界を考える際には非定常性の影響は小さい。過去におい ては，底質粒径と波高や波長の関数として移動限界水深 を与える扱いが多かったが，波・流れ共存場への拡張を 考えれば移動限界の底面せん断応力で扱った方がよい.

Madsen・Grant ${ }^{48)}$ は，一方向流中での移動限界に対す るシールズ曲線が，波動場に対しても近似的に適用でき ることを示した。

移動限界を超えて底面せん断応力が増加するにつれ て，底質の移動形態は，掃流往復運動，砂漣上の渦によ る浮遊，シートフロー状の移動亡，段階的に移行する. 波動場における移動形態の区分は，金子49)や Shibaya$\mathrm{ma} \cdot$ Horikawa $\mathrm{a}^{50)}$ 等によりまとめられているが，波と流 れが重なった場合についてはまだほとんご研究がなされ ていない。

海岸での漂砂は沿岸漂砂と岸沖漂砂に分けて扱われる ことが多く,前者の漂砂量式として次式がよく使われる。

$Q_{x}=\alpha E_{i}^{n}, \quad E_{i}=\left(E c_{g}\right)_{b} \sin \theta_{b} \cos \theta_{b}$

ここで, $Q_{x}$ は沿岸漂砂量, $E, c_{g}, \theta$ は波のエネルギー, 群速度, 波向角で添字 $b$ は砕波点での值を意味する. 一方, 岸沖方向の漂砂については往復運動の差としての 正味の量が問題となるが，一般的な条件に対して正味の 漂砂量を与える算定式は確立されていない，波半周期間 の平均漂砂量 $\bar{q}$ については, Madsen・Grant ${ }^{48)}$ による 式,

$\bar{\phi}=\bar{q} / w_{0} d=\beta \psi_{m}^{3}$

が適用できそうである.ただし $w_{0}$ は沈降速度， $d$ は粒 径, $\phi_{m}$ は底面せん断応力の振幅で定義したシールズ数 であり，限界シールズ数の 2 倍以上ならば $\beta$ は 12.5 の
值をとる.この式は Einstein・Brown の流砂量式を波 動場に準用して求められたものであるが，山下・沢本 $ら^{51)}$ は，砂粒子運動の素過程に立脚した扱いにより，ほ ぼ同一の関係を得ている．砂漣が発生し浮遊砂が卓越す る条件や，砂辑が消滅してシートフロー状の砂移動が生 じる場合についても，上式と同様の関係が成立すること が報告されている ${ }^{50), 52)}$.

\section{（2） 河口周辺の地形}

河口から供給される土砂を運び去る沿岸の波や流れの 強さにより，河口入江（エスチュアリ）の形態をとった り三角州や尖角岬が形成されたりする．また日本の多く の河口のように土砂が豊富な場合には河口砂州がみられ る. 山本 ${ }^{53)}$ は河口砂州の発生の仕方を 2 種に大別した。 1 つは洪水後の河口前面の浅瀬に波により打ち上げられ て生じる二次元砂州であり，もう 1 つは河口がある程度 深い場合に生じる三次元砂州で，河川流と波との作用の 強弱によりその形状が変化する（図一6）.

日本の河川では流出の変動が大きく, 河と海の作用の バランスのもとで形成される河口地形の変動も大きいた め，人工構造物によりこれを制御する試みがなされてき た. 延長 $10 \mathrm{~km}$ 以上の全国 513 河川について調べてみ ると, 人工構造物がほとんどないとみてよい自然河口は， 大河川（流長 $100 \mathrm{~km}$ 以上）では 52 河川中 3 河川に過 ぎず，中小河川 (10 99km) でも $20 \%$ 程度である。 関東・中部では特に自然河口が少ない，自然河口 95 中 $40 \%$ では砂州が存在するのに対し，人工河口 418 中で 砂州が存在するのは約 $20 \%$ であり，特に両側に導流堤 （突堤）を有する河口 63 中で河口に砂州が発生してい るのは 4 例に過ぎない.

\section{（3） 河口部の土砂収支}

a）土砂収支の考え方

(1) 現象のスケール

河口における土砂収支をどのような時間空間スケール で考えるかはきわめて重要である．山本 ${ }^{54)}$ は考えられる 時間スケールとして, 1 万年のオーダーの地質学的時間,

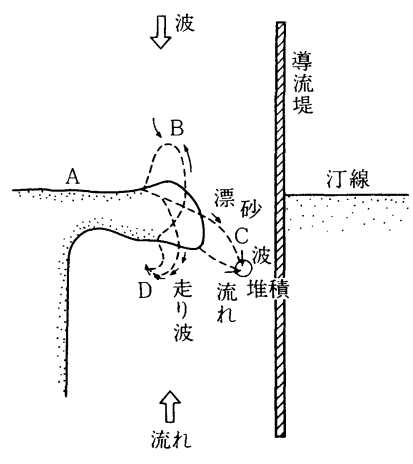

図一6 河口砂州の变化 
1000 年から 100 年, 数 10 年から 1 年, 月から週, 時間 から分程度への区分をしており，また空間スケールとし ては岬などで区切られた砂浜の海岸線延長程度を中ス ケールとして, 工学的には海岸線の向きや侵食堆積傾向 などの大スケールの条件を境界条件とし砂州の消長など の中規模スケールの現象を解析予測すればよいと述べて いる.

(2) 河口における土砂循環の支配要因

河口では河川流, 波浪, 潮汐などが主外力であり, 潮 汐と波浪の影響の大小により, 河口を潮汐支配型と波浪 支配型に分けることがある．わが国のほとんどの河口は 波浪支配型で，河川流と波浪が主要な営力となる.

(3) 土砂収支

海岸の土砂収支を考察する場合には，できれば岬など によって区切られた区間を対象とすると扱いやすい. 隣 接海岸より流入する沿岸漂砂や河川からの流送土砂およ び海崖からの土砂が主な漂砂供給源であり, 他方, 流出 する沿岸漂砂および離岸漂砂が主な流出要因となる.

土砂供給のうち最も重要なのは河川からの流送土砂で ある. 図一7 は大河津分水工事に伴う新信濃川の河口デ ルタの形成を示し，約 10 年程度の時間スケールの土砂 収支の好例である.もっともわが国では近年，ダム堆砂 などの原因により河川からの土砂供給量が減少し，河口 デルタが縮小してきている例が多い. なお，河川の流送 土砂量については種々の流砂量公式が提案されている が，どのような粒径の底質がいかなる割合で海岸土砂収 支に寄与するかはほとんどわかっていない.

海崖の後退も海岸の土砂収支の観点からは供給の 1 つ である、堀川・砂村 ${ }^{55}$ 等により調査研究がなされている が，たとえば屏風ヶ浦海岸での崩落土砂量は年間 30 万 $\mathrm{m}^{3}$ にも及ぶといわれる.

b ）河ロデルタの形成

河口デルタの形成には 2 つの要因があるといわれる. その 1 つは, 河川が海や湖などの広い水域に流入すると, 流送土砂がデル夕状に堆積するものであって, 細粒の土 砂は沖へ運ばれ, 比較的粗いものが沿岸に残留してデル 夕地形を形成する.

(1) 波浪の影響が無視できる場合

河川が波浪などの影響を受けない水域に流入する場合 のデルタ形成について, Chang ${ }^{56)}$ は実験を行い, 流送
土砂量を一定とするとデル夕の面積は時間とともに直線 的に増加することを見出した. Chang はこのデルタ形 成過程を説明するために，数值モデルによる検討も行っ ている，すなわち，デル夕上を流れる水流はその幅が場 所と時間の関数となるとして通常の開水路水流の基礎方 程式を用い, さらに流砂の連続式ならびに流れエネル ギーの最小の原理を適用することによって，デルタの形 成とそれに伴う流水の特性を求めた。網状のような流路 系に対しての適用は困難であるが，デル夕の形成過程を 知る 1 つの方法として評価できる.

（2) 波浪の影響が顕著な場合

デルタ形成に波浪の影響が支配的な場合に対する扱い の多くは, 海浜変形の一次元 (1-line) モデルの応用と してなされてきた ${ }^{57) \sim 61)}$. たとえば土屋・安田 ${ }^{59)}$ は，漂 砂の連続方程式に若干の近似を施して得られる次式

$$
\frac{\partial y_{0}}{\partial t}=\frac{1}{(1-\lambda) h_{0}}\left[\left(\frac{\partial Q_{x}}{\partial \theta_{b}}\right)_{0} \frac{\partial^{2} y_{0}}{\partial x^{2}}+q_{R}(x, t)\right]
$$

と式（7）の形の沿岸漂砂量式を組み合わせてその解析 解を求めている.ただし, $y_{0}$ は初期海岸線よりの前進量, $h_{0}$ は漂砂帯外縁水深, $\lambda$ は底質空隙率, $\theta_{b}$ は砕波角, $Q_{x}$ は沿岸漂砂量, $q_{R}$ は単位幅当たりの河口流送土砂量で ある. 図一8 は結果の例で, 汀線位置 $y_{0}$ と河口幅 $B$ は $h_{0}$ で無次元化してある. また, $t^{*}=t\left(\partial Q_{x} / \partial \theta_{b}\right) /$ $(1-\lambda) h_{0}^{3}$ は無次元時間である.これによると無次元河口 幅 $B^{*}=B / h_{0}$ のデルタ形状に及ぼす影響は先端部を除 いてはそれほどには著しくない. 解析解が求まるのはご く単純な条件に対してのみであり，一般には数値計算が 必要となる ${ }^{60), 61)}$.

\section{c）河口デルタの縮小}

波浪の作用による河口デルタの縮小過程についても， 形成過程に対すると同様の理論的扱いがなされている.

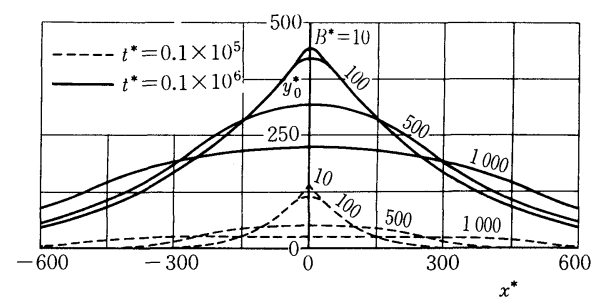

図一8 河ロデルタの発達とその形状 ${ }^{59)}$

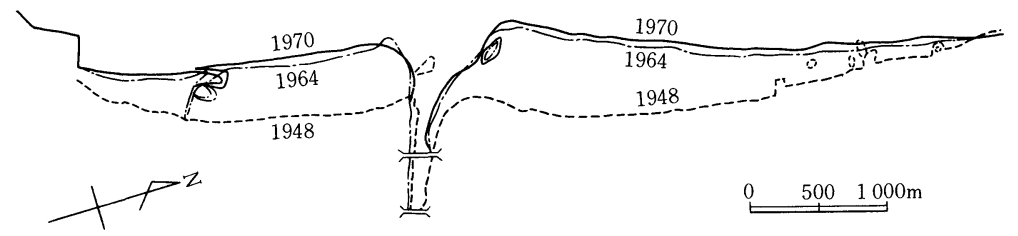

図一7 新信濃川河口におけるデルタの発達 


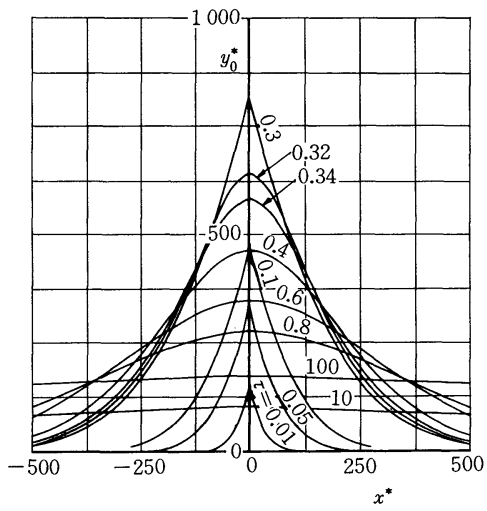

図-9 河ロデルタの縮小過程 ${ }^{59)}$

図一9 は計算結果の例で，デル夕形成の途中で河口から の流送土砂量が減少した場合の縮小過程を示す。流送土 砂の減少効果はまずデルタ先端部に現われるが，河口か ら十分に離れた場所ではなお堆積傾向を続け，減少後の 流送土砂量に対応した平衡デル夕地形へと漸近していく

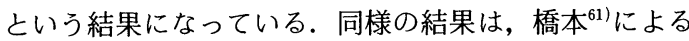
数值計算でも得られているが，精度のよい定量的予測は 今後の課題である.

近年目立つ河口周辺での海岸侵食は，流送土砂量の減 少による河口デル夕の縮小としてとらえることが可能な 場合が多いものと思われる.

（4）河口砂州と河口断面変化

a ）河口砂州の実態

河口砂州の実態についてはかなり古くから調査されて いるが，特に島根県神戸川河口に関する佐藤 ${ }^{62)}$ の先駆的 研究は注目される.潮汐の影響は小さいので無視し, 漂 砂を生じさせる波浪にかかわる量として海風風速を選 び，それと河口流量とが河口幅とどのような関係にある かを調べた。 その結果，流量が小さく海風風速が大なる ほど河口幅は小さくなるが，流量が $10 \mathrm{~m}^{3} / \mathrm{s}$ を下らなけ れば河口の完全閉塞は生じないことなどが見出された.

次に本間・堀川ら ${ }^{63)}$ の相模川河口に関する調査研究が 挙げられる．相模川では漂砂による河口閉塞傾向が甚だ しく漁船の航行等に支障をきたしていたので, 1951 年 より導流堤工事が行われ，これに伴い調査がなされた。 そして相模川河口砂州の消長にとり最も重要な要素とし て固有流量と潮汐作用が指摘されるとともに, 固有流量 と河口幅の間の関係や，流量低下率と河口閉塞率の関係 等が調べられた. 相模川ではその後も数多くの調査がな されている64).

島根県江ノ川河口における河口砂州の変遷過程をみる と, 1960 年頃までは河口砂州の変動が激しく左右両岸 から砂州が伸びていたが, 左岸に導流堤を設置した後は,
河口砂州は常に右岸から発達している．このような導流 堤の効果は他の河口においても認められている.

\section{b ） 河口砂州の水理特性}

河口砂州の消長過程には波浪や河川流，潮流，河口付 近の地形, 人工構造物などが影響するので, その水理特 性はきわめて複雑であり，それを解明するためには単純 化した条件のもとで各要素の効果を調べる必要がある.

(1) 河口砂州に関する二次元実験の結果

河川流と波浪による河口砂州の形成に関する二次元実 験の結果に基づき，野田 ${ }^{65)}$ は河口砂州の発生形態を次の ように分類した. 砂州頂面が水面上に出る I 型(堆積型), 水面下にある II 型（遷移型）および河口付近の砂が沖に 運ばれる III型（侵食型）の 3 段階であり，どの形態をと るかは河床水深にも大きく影響される. 鮏川 ${ }^{66)}$ はこの河 床水深の影響を, 一般の海浜での沿岸砂州の発生限界に おける沖波波高の効果の中に含めて考え, $H_{0}^{\prime}=\alpha H_{0}$ と して実測沖波波高 $H_{0}$ を換算した $H_{0}^{\prime}$ を導入し，砂州の 形態 (発生限界) を $H_{0}^{\prime} / L_{0}$ と $H_{0}^{\prime} / d\left(L_{0}\right.$ は沖波波長, $d$ は粒径) との関係で図一10のように整理した.ただし， $\alpha$ は

$$
\alpha=1+\left[0.55+1000\left(\bar{u} / c_{0}\right)^{1.5}\right]\left(h_{r} / H_{0}\right)^{1.5}
$$

で与えられる. $h_{r}$ は河口部水深, $\bar{u}$ は河川流の平均流速, $c_{0}$ は沖波の波速である.

(2) 河口の断面特性

潮流の影響が著しい河口では; その最小流水断面積が タイダルプリズムとほぼ比例関係にあることが, $\mathrm{O}^{\prime} \mathrm{Brien}^{67)}$ によりアメリカ太平洋岸の河口調査に基づき 指摘された。吉高・島田 ${ }^{68)}$ は, 土佐湾沿岸や宮崎海岸の

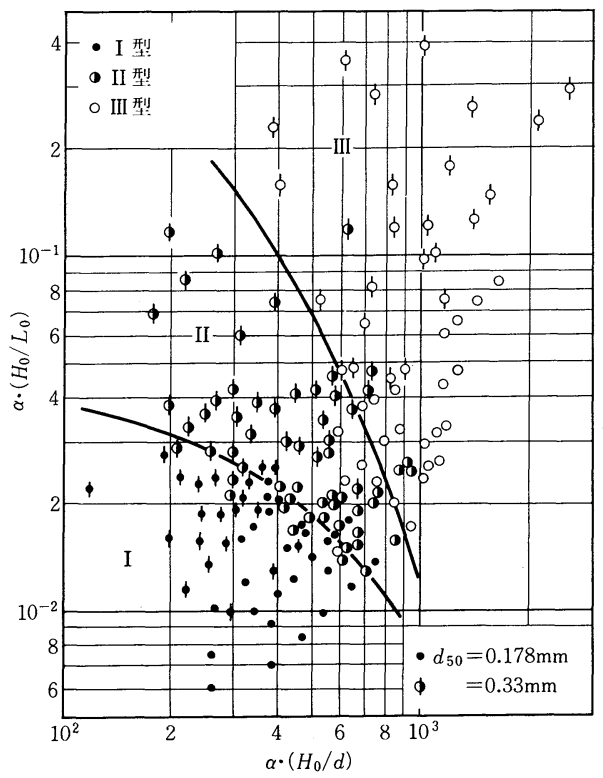

図一10 河口砂州の発生限界 ${ }^{66}$ 
河口に対する資料を整理し，わが国の河川でも同一の傾 向があるとした.

一方，潮流の影響が小さいときの流水断面積あるいは 河口幅は, 河川流と沿岸漂砂の相互作用によって定まる. 洪水時等に拡大した河口断面は, その後の漂砂で徐々に 縮小し低水時の河川流量に対応する断面に近づく．椹 木 ${ }^{69}$ は実験によって, 断面縮小の程度と河川流速（掃流 力）および沿岸漂砂量の関係を求めた.

出水時に拡幅された河口幅と直接関係する流量を, 佐 藤 ${ }^{62)}$ は河幅支配流量とよび, 本間・堀川ら ${ }^{63)}$ は河川固有 流量とよんでいる.これに対し, 平・低水時に縮小して 平衡状態になったときの最小河口幅 $\left(B_{e}\right)$ に対応する 流量を, 野田 ${ }^{64)}$ は河幅下限流量 $\left(Q_{m}\right)$ とよび，神戸川 や江ノ川について $B_{e}$ と $Q_{m}$ の関係を調べた. 両者の関 係は山本 ${ }^{53), 70)}$ により他の諸河川についても調べられてお り, $B_{e} \propto\left(Q_{m}\right)^{n}$ の関係が見出されているものの, 指数 $n$ や比例係数の值は各河川により異なる. 図一11に天神 川と神戸川の河口幅 $B$ と流量 $Q$ の関係を示す.

c ） 河口断面の変化過程の数值モデル

河口砂州研究の主要課題になりつつある河口断面の変 化過程の数值予測モデルには, 洪水による河口の拡幅過 程を対象とするものと, 沿岸漂砂と河川流とが均衡する までの河口幅縮小過程を計算するものとがある.

(1) 河口滞砂のフラッシュに対するモデル

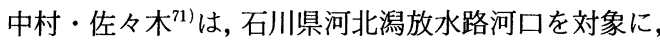
洪水前の滞砂状況すなわち河口断面積, 洪水期間中の流 量と河口付近の水位勾配, および洪水後の河口断面積を 測定し，これらのデータから洪水期間中の河口断面積の 増大過程を数値計算により追算した. 水位勾配から摩擦 速度を求めて Brown 型掃流砂量公式により河口の掃流 砂量を評価するとともに, 粗度係数 $n$ の評価も行って いる. その結果, 掃流砂量公式中の係数值として通常い われている 10 に対し 1.2 程度にとる必要があることや, $n$ が 0.05 程度と大きな值をとることがわかった.

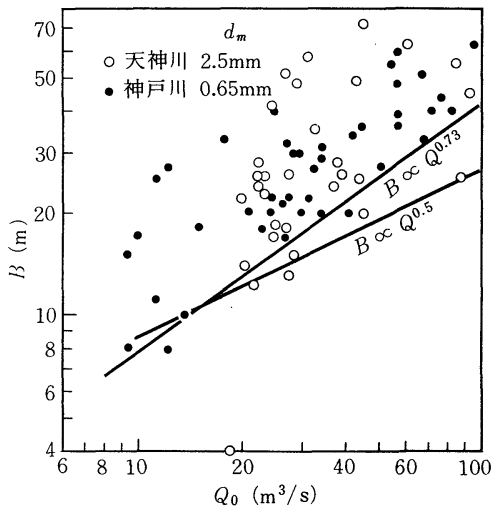

図一11 河口幅と流量の関係 ${ }^{70)}$
(2) 河口断面の変化モデル

河川流と潮流により河口から海域へ掃流される単位幅 当たりの流砂量を $q_{B}$, 波浪による単位幅当たり沿岸漂 砂量を $Q_{u}$ とし, 河川流と潮汐流が河口の土砂を排除す る一方, 漂砂が河口に砂碟を搬入すると考えると, 河口 部の土砂量 $V$ の変化は次式で与えられる.

$(1-\lambda) d V / d t=\left(Q_{u}-q_{B}\right) B$

ここに $B$ は河口幅, $\lambda$ は砂の空隙率. 青田・首藤 ${ }^{72)}$ は, $V=L h B$ において河口砂州の奥行幅 $L$ と水深 $h$ を一定 とし， $q_{B}$ には Kalinske - Brown 型掃流砂量式, $Q_{u}$ に は Caldwell 型漂砂量式を用いて, 上式により阿武隈川 の河口幅変化過程を計算している. また流量や波浪条件 が一定の場合に対する安定河口幅の式を与えている.

一方宇多 ${ }^{73)}$ は, 海浜変形の 1-line モデルを適用して, 相模川河口における砂州の発達過程を計算し, 実測デー タにより検証した.

\section{4. 河口処理工法とその影響}

\section{（1） 河口閉塞防止工法}

a ）従来の河口閉塞対策

(1) 導流堤工法とその効果

従来の河口処理工法の代表的なものとして導流堤工法 がある. 導流堤が河川の疎通能力と掃流能力を増大して, 河口前面に堆積した砂州をフラッシュする効果をもつこ とは昔から認められている. しかしそのフラッシュ効果 は導流堤の長さや開口部の幅により大きく変化する.

椹木・小舟 ${ }^{74}$ は, 導流堤の長さと開口幅の変化に伴う 河川流の掃流力と砂州河口部断面積の関係を移動床実験 で調へ，導流堤が短い場合には前面に砂州が形成される ので流出断面積は導流堤の開口幅により規定されるこ と，導流堤が十分に長い場合には砂州の発生が直接抑制 されて初期の開口部断面積が保たれることなどを見出し た.

導流堤には沿岸漂砂を遮断して河口砂州の発生を阻止 する効果もあるが，その場合でも導流堤はある程度の長 さをもたないと砂州の抑止効果は期待できない年，ただ し, 沿岸漂砂の遮断により漂砂下手側の海岸に侵食を生 じることも多く，また図一12に示すような河口遮蔽型 の導流堤の場合には遮蔽域では波高減衰のため堆砂が生 じるおそれもある. 図一13 の垂直型導流堤の場合でも， 砕波帯内にしか延びていないと, 途中に堆砂が生じる ${ }^{76)}$.

(2) 導流堤の配置形状

導流堤の基本的配置は，図一12(a) と図一13に示さ れる二本導流堤と, 図一12(b) と図一14 のような一本 導流堤に大別できる. 二本導流堤は, 砂浜海岸に河口が あり沿岸漂砂が卓越する場合にそれを阻止することを主 目的として設置される場合が多く，沿岸漂砂の卓越方向 


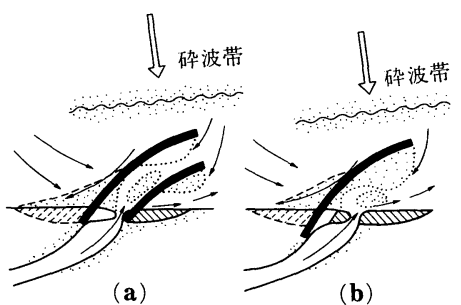

(a)

(b)

図一12 河口遮蔽型導流堤

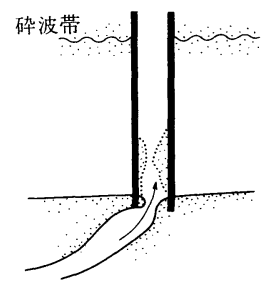

図一13 垂直型算流堤

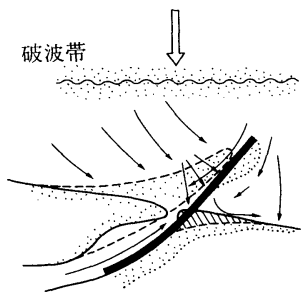

図一14 一本導流堤

が変動する海岸では図一13の垂直型が適する．一本導 流堤は, 他岸側が崖の場合や河川の固有流量がある程度 あって河口の位置を固定しようとする場合に用いられ る.

導流堤の効果は河川流や波浪・海浜流の条件に左右さ れるため一律には論じ難く, 配置計画に際しては水理模 型実験により決定しようとする試みがなされている77). 砕波現象等を含むため一般に無ひずみ模型で実験がなさ れ，底質移動の相似性を満足するために軽量底質を用い ることが多い。しかしながら，波と流れ，およびそれぞ れの作用下での底質移動の相似性をすべて満たすことは 一般に困難である. 近年では数值シミュレーション手法 も用いられるようになってきだ吾)

\section{(3) 暗渠工法}

計画流量が小さく陸地地盤が高い場合で，波の打上げ 高が大きくて漂砂が導流堤を越えて河道内に堆積しやす いところでは, 暗渠工法がよく用いられる. しかし暗渠 工法に関する水理学的研究はきわめて少ない.

豊島 ${ }^{76), 79)}$ は各地の暗渠工法を実地踏査し, 成功例の特 徵を次のようにまとめた。1）暗渠の吐出口の底高を高 くとる，2）暗渠の正面は閉じてゲートか横吹き式（図

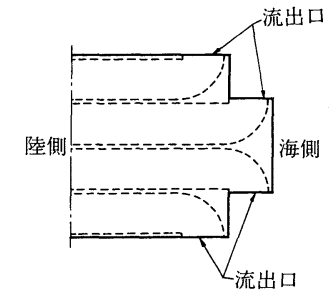

図一15 横吹き式暗渠（平面図）

一15）を採用する，3）暗渠を多列にする，4）暗渠の吐 出口の断面を入口断面より低くする，5）吐出口の形状 を傾斜型あるいは丸型にし波力の作用を弱める。，一方， 失敗例の原因としては, 波力による吐出口の破損や暗渠 内への堆砂による機能喪失等が挙げられる.

(4) 人工開削

人工開削は目的により 2 つに分類される.1つは河口 を大幅に掘削し長期間にわたっての水深と河積維持を目 指すものであり，開削後の堆積に対する事前予測調查が 必要となる。一般に波の影響の小さい河口において採用 されることが多いので, 河川の流下土砂による堆砂計算 が行われる ${ }^{80)}$. いま 1 つは, 砂州の一部を出水前に開削 して砂州のフラッシュを助けるものである．この場合に は, 波が存在する条件での河川流のフラッシュ能力 ${ }^{69)}$ 調べておく必要がある.

(5) 飛砂対策

静岡県菊川の例にみられるように，飛砂が河口閉塞の 原因の 1 つになる場合も少なくない，飛砂そのものに関 しては古くから研究されており, 飛砂量と摩擦速度の関 係等も明らかにされているが，飛砂防止工に対しては一 層の研究が望まれる.

b ） 新しい河口閉塞対策工法

いまだ実績はそしいが，今後の発展性のある河口閉塞 対策工法を以下に列挙する.

(1) 離岸堤工法

離岸堤 2 基を河口部前面に設置することにより，河口 隣接海岸の侵食防止と, トンボロ形成による河口部の安 定を図れる可能性がある.ただし河川の疎通能力の向上 はあまり期待できない.

(2) 離岸堤亡暗渠工法の併用

横吹き式の暗渠のみでは沿岸漂砂により開口部に砂が 堆積し排水機能が低下する危険性が大きいので, 離岸堤 を 2 基設置し，その開口部に横吹き孔を配置することが 考えられる.

(3) 新暗渠工法

ハワイ大学で開発された工法で, $\mathrm{V}$ 字型の有孔スラブ 構造を有している ${ }^{81)}$. 閉塞状態で河川流による上流部水 位上昇が生じると, V字型最奥部付近の閉塞砂州が浸透 
水によりまず崩壊し，それが全体に進むことを期待する ものである.

(4) 貯砂ポケット工法

河川流による流送土砂が河口部に堆積するのを防ぐた めに, 航路部の上流にあたる一部をあらかじめ深く掘り 下げておく方法であるが，貯砂ポケットによる捕砂率や 堆積過程に関する研究 ${ }^{80)}$ の進展が望まれる.

C ）河口対策工法の周辺部への影響

導流堤による閉塞防止効果をあげるにはある程度の水 深まで導流堤を延長する必要があるが, これにより沿岸 漂砂が阻止され下手側海岸に侵食を生じる．この下手側 の侵食対策のためには, サンドバイパス工法等が必要と なる。

(1) 暗渠工法の影響

導流堤の場合と同様に，下手側に著しい侵食を招く場 合があり，また暗渠基部で洗掘を生じやすい.

(2) 人工開削および貯砂ポケット工法の影響

開削や掘削に伴う水深変化のために，波浪や流れの場 も変化し，その影響が周辺部の地形変化となって現われ るおそれがある。

\section{（2）河口部の水質対策}

a ） 海水侵入長の増大防止と塩害対策

河道内への海水侵入長の増大をもたらす主要な原因に は，1）取水量の増大による流量の減少，2）河口処理に 伴う河口部の水深と流路幅の増大，3）掘削や拡幅等の 河道整正，などがある ${ }^{82)}$

対策としては以下の方法が挙げられる．1）河口幅を 小さくしたり，洪水時にフラッシュ可能な程度まで河口 砂州の発達を促進することにより，河口部での損失を大 きくする．2）潮止工や河口堰により海水侵入を強制的 に制限する．河床高が高くなっている区間があるときに それを維持して海水侵入を抑えている例もある．3）河 口前面の海域部の浅瀬を維持し，水温上昇により海水密 度を低下させるとともに砕波によって淡水との混合を促 進する.4)気泡の放出や, 流路幅急縮による逆流渦によっ て，開口付近での成層度を小さくする．5）ダム放流等 により河川流量を増大させる.6)取水時間を調整したり, 取水口の位置を工夫する. 侵入長は季節的な流量と水温 の変化や潮位変化によっても変動を示す ${ }^{83)}$ が，これを予 測するとともに各対策工の効果を定量的に把握しておく ことが肝要である.

塩害 ${ }^{84)}$ に対する対策には以下の方法が単独あるいは複 合的にとられる．1）シートウォールや矢板の設置，2) 高水敷の表面を不浸透性の材料で覆うブランケット工 法，3）塩分を含む河川水の堤内地への侵入を防ぐため の承水路，4）伏流水や浅層地下水の汲み上げ規制，5） 客土や地上げ.

\section{b ） 停滞水の水質悪化対策とへドロの除去}

河口閉塞に伴う停滞水の水質悪化対策としては，1） 河口流水断面の拡大による水はけ改善，2）感潮部水面 積の増大による入退潮量の増加，3）ダム操作による河 川流量の増大，4）净化用水の導入，などがあるが，浄 化装置を設置して污濁負荷量を減らすことが基本的解決 策である.

河口部に沈降堆積したへドロの除去には，経済性のほ かに, ヘドロの巻き上げ85) と沈降現象, および溶出現象 ${ }^{86)}$ なよ゙が問題となる。

\section{（3） 河口部の波浪対策}

高潮時等に河道内に波浪が侵入して両岸の堤防に打上 げ越波を生じる場合があり，また波により河口に砂州が 形成されると洪水の疎通が悪くなり漁船などの航行に支 障をきたす。

河道内への波浪の侵入を防ぐ方法の 1 つとして，河口 砂州を維持し，浅瀬によって砕波を生じさせることも行 われている. 須賀・山田 ${ }^{87)}$ は，江戸川河口部を対象にし て模型実験を行い，浅瀬による河道内の波高減衰を調べ た.また一般に河道中央では水深が大きく両岸では浅い が,このような断面形を維持すれば，河道内に入った波 が両側に向かって屈折し砕波することによりエネルギー を失うことも期待できる.

導流堤は河口の位置を固定し河口部の河積を確保する ために設けられるのが通常だが，河口部への波の侵入を 防ぐためにも用いられる．日立港の拡張のために久慈川 の河口を南へ移した際には，河口付近の河道が直接外海 に向き波浪の侵入が増大するおそれが生じたので，模型 実験を行って，波浪侵入を防止し，洪水流出に支障をき たさないための導流堤の配置等を決定した ${ }^{88)}$.

洪水の流下に支障を与えずに波の侵入を防ぐ工法とし て河口部の河道両岸に消波工を設置する場合がある．こ れは上流に向かって進む波が消波工によりエネルギーを 失うことと，堤防への打上げ高が減少することをねらっ たものである．松村 ${ }^{89)}$ の実験によれば，消波工を設置し た場合には打上げ高は約半分となり，河道内波高も低下 する．河口対策としての実施例はないが他に提案検討さ れている波浪侵入対策工法としては，橋梁 ${ }^{90)}$, 暗渠, 離 岸堤，浮防波堤などがある。

\section{(4) 航 路 維 持}

河口航路の維持対策には，1）河道変更（分水）によ る河川流下土砂量の低減, 2)流れの制御による水深維持, 3）浚渫による水深維持等の方法がある.

わが国において河口港の埋没対策として河道の分離が 実施された例としては, 新潟港 (大河津分水, 関屋分水), 秋田港 (雄物川放水路), 伏木港 (生川の分離), 石巻港 (北 上川柳津分水) などが挙げられる．これらの分水工は， 
河川の洪水制御に主目的があったが，河口部への流下土 砂の減少にも大きな効果をもたらした。ただし，微粒浮 遊物を多量に含有する大陸の大河川にあっては, 流速の 低減が浮遊物の沈降と埋没を助長する場合も考えられ る.

河道内の流れを水制工や導流堤によって制御して航路 部分に集中させ, 河川排出土砂の沈降堆積を防止し, あ わせて堆積土砂をフラッシュする工法もとられている. また, 河道内において航路泊地部分を河道部分から堤体 によって区割する背割堤も，酒田港や新潟港で実施され ている.

河口港においては維持浚渫がどうしても必要となるの で, 効率よく, 港湾機能を阻害せずに実施するために, ポケット浚渫等の方法がとられている.

\section{5. 河口部の調査}

\section{（1）調查の目的と調查項目}

河口処理対策に直接役立つ資料を得るための調査か, または河口部での現象解明に重点を置くのかにより, 調 査の内容, 規模, 方法が異なる. 前者の場合は, 個々の 河口部の特性把握という地域性の強いものになり, 水理 現象の調査のほかに,社会・経済・環境調査が行われる. 一方, 現地での実際現象を正確に把握し, 理論的考察に 基づいて得られた知見を普遍化しようとする研究指向型 の現地観測も盛んに行われるようになってきた。

水理現象の計測観測を行う際には, 対象亡する現象の 時間的空間的規模をも十分考慮して調査法を決定し，ま た得られたデータの解釈を行うことが重要である ${ }^{91}$. 現 在規準化されている河口部の調査法 ${ }^{92), 93)}$ は，中間的規模 以上の河口現象を対象としているが，河口水理現象の解 明のためには，微視的規模のデー夕も不可欠である．ま た, 水理量,水質,地形等の計測をできるだけ同時に行い, 諸因子間の相互関係を明確にし得るような観測を行うこ とが肝要である.

\section{（2）水理量観測法}

a ）流速や流況の観測

(1) 流速・流況観測法

固定点での流速測定には, 回転型流向流速計, 電磁流 速計, 超音波流速計等が用いられる. かつては回転型流 速計が使われることが多かったが，河口域での流れの特 徵である流速変動に対する応答性が良好でないため, 電 磁流速計や超音波流速計の使用頻度が増えている ${ }^{94), 95)}$. また，河口部での諸現象に対する乱れの効果の重要性が 認識されるようになるにつれ，上記の流速計のほかに， 現地観測用に改造された熱膜流速計 ${ }^{96)}$ やレーザドプラー 流速計 ${ }^{97}$ 等も使用されている.

流速測定用の追跡浮子に関しては，表層付近のみなら
ず中下層での流速を測るための工夫がなされてきた ${ }^{98)}$. また，流況観測には浮子のほかに染料や水の温度も卜 レーサとして利用され, 航空機, バルーン, 人工衛星等 からの写真撮影がなされている. 今後のリモートセンシ ング技術の向上により, より高精度で広範囲の流況デー 夕の取得が可能となることが期待される.

(2) 河口部での流速・流況の観測例

田中・首藤 ${ }^{999}$ は，福島県鮫川河口での流速と水位変動 の同時測定を，二成分電磁流速計と容量式波高計を使用 して実施した．それによれば，潮汐に起因する周期的流 速変化か認められるが, 河口付近では重複波性になるた め水位変動との間に明瞭な位相差が存在する. また，順 逆流の変換期には，成層化のため上下層での流向が異な り流向変動が激しいことや,乱れ強度の時空間分布から, 落潮時に水面より生じた乱れが下層部に広がっていくこ とを報告している.

利根川河口での洪水時の流況を調べるために，須賀・ 高橋 ${ }^{100)}$ は航空写真を利用し，表面流速分布の図化を行 うとともに, 河道湾曲部のらせん流によるボイルの形成 や導流堤沖側での内部ジャンプに関する解析を行ってい る.

田城ら ${ }^{977}$ は天塩川河口部の二層流場の乱れをレーザド プラー流速計により実測した. 各水深での乱れ強度の分 布特性によれば，水面での風波による乱れに次いで，界 面で発生する乱れが大きい. また, 平均流速変動のパワー スペクトルのピーク周波数が界面位の変動周波数にほほ 一致する.

鷲見 ${ }^{101)}$ は 2 台の三成分超音波流速計を用いて東京湾 内での潮流流速の鉛直分布を測定し, 平均流の定常性が 高い状況では乱れの周波数スペクトルが $-5 / 3$ 乗則に従 うが海底面付近の境界層内は層流であることを見出し た。

\section{b）水位・波浪の観測法}

河川水位や潮位のように変動が緩やかな場合と，波浪 のように水面変動速度が大きい場合とでは, その測定法 も当然異なる．河川の水位や潮位の観測には，観測装置 内の水位変化を自記水位計で記録する方法と, 水位標等 を使用して目視により水位を測定する方法とがある.

波浪による水面変動測定は, 電気抵抗式, 容量式, 超 音波式, 水圧式, ブイ式などの波高計や，写真撮影等の 光学的記録による方法によりなされる. 波高計は定点で の水面変動を測定するものであるから, 波向や波の変形 などを調べるためには波高計アレーとして用いる必要が ある.これに対し光学的手法は，波向などの観測に適す るが，水面波形や波高データを得るにはステレオ写真撮 影を行わねばならない。

\section{（3）河口地形調查法}


汀線や地上地形の測量は, 旧来の測量手法, あるいは 航空写真測量によりなされる. 深浅測量は, 浅い水域で はスタッフやトランシット, レベルを用いたり, 格子状 に配置したポールの水底高を直接読み取るポールアレイ 法によりなされ, 深い水域は船上から重鍾や音響測深機 を用いてなされる.

水面下の地形を空中写真より求める方法として，1) ステレオ画像を用いる手法, 2) 画像の色調あるいは濃 淡と水深の関係を利用する手法等がある. 前者は日本海 沿岸で水深 $10 \mathrm{~m}$ までの海底地形測量に用いられてい る. 後者としては, 堀川・砂村 ${ }^{102)} や$ 宇多・橋本 ${ }^{103)}$ 等の 試みがあるが, 画像の色調が底質条件や水中の浮遊物, 気泡の混入等に影響される点が問題である.

\section{（4）水質調查法}

a ）調査の対象となる水質と関連因子

河口部の力学的現象に最も大きな影響を与える水質項 目は塩分であり, 他には水温や浮遊物の濃度等が密度の 変化を通して流れに影響する. 水質調査においては, 水 質分布構造の決定因子までも含めた観測測定を行う必要 があるが，実際にはすべての因子を詳細に測定するのは 困難であるので，最も重要な因子を予測して臨むことに なる.

\section{b ）現地観測の方法}

\section{(1) 非定常現象の観測}

密度界面を有しない河口部の場合は，通常の水質計や 流速計を用い，いくつかの点で数時間おきに観測すれば 現象がほぼ把握できる．しかし，緩混合や弱混合の河口 部にはこれでは不十分なことが多い．特に緩混合の場合 には，超音波測深機による界面観測が不可能に近いこと が調查を一層困難にしているが, 観測領域は比較的短距 離であるため数地点に的を絞って定地観測を行えば，潮 汐周期の流速や水質の変動を把握できる ${ }^{104)}$.

これに対し弱混合型の河川では, 定常流に近い流況に なっており，超音波測深機による界面測定や各種自記記 録計器の使用が有効であって, 観測例もきわめて多い. たとえば吉田・谷藤 ${ }^{105}$ は, 低水時の天塩川河口水系で 大規模な総合的観測を実施した。 また，非定常現象の 1 つとして重要な界面変動の観測には, ステップ式界面 計 ${ }^{106)}$ や連続追尾式測定法 ${ }^{107)}$ 等も工夫されている.

\section{(2) 界面破壊現象の観測}

界面破壊は河口部で海水と河川水とが混合する最初の 段階であり, その機構解明は古くからの重要課題である. 水平距離にして数十 $\mathrm{cm}$ を越す領域にわたる界面破壊で あれば超音波測深機による観測が有効である ${ }^{108), 109)}$. 界 面破壊現象をさらに詳細に調べるために, 界面を色素で 可視化し, 水中カメラで観測する方法も試みられてい る $^{110)}$.

\section{(3) 河口流出水の拡散域の観測}

海域に拡散する河川水の水質分布構造については, 水 質計や流速計を用いた観測が主になされてきた．河口の 近傍における観測は，当分は従来の方法により実施せざ るを得ないが, 沖合に拡散した河川水についてはリモー トセンシング法 ${ }^{111}$ が有効であり, 将来は拡散水観測法 の主流となるであろう．ただし，拡散過程を力学的に把 握するためには，乱れをも含む流速や流況，およびいく つかの測点での鉛直構造デー夕等をも取得することが肝 要である.

\section{参 考 文 献}

1) Hansen, D. V. and Rattray, M. Jr. : New dimensions in estuarine classification, Limnol. Oceanog., Vol.11, 1966.

2）須賀堯三：感潮河川における塩水くさびの水理に関する 基礎的研究, 土木研究所資料, 第 1537 号, 1979.

3) Einstein, H.A. and Krone, R. B. : Experiments to determine modes of cohesive sediment transport in salt water, J. Geophys. Res., Vol.67, No. 4, 1962.

4) Einstein, H. A. and Krone, R. B. : Estuarine sediment transport patterns, Proc. ASCE, Vol. 87, No. HY 2, 1961.

5) Kendrick, M.P. : Siltation problems in relation to the Thames barrier, Phil. Trans. Roy. Soc. Lond., A 272, 1972.

6）大坪国順：底泥の物性及び流送特性に関する実験的研究, 国立公害研究所研究報告, 第 42 号, 1983.

7) Gordon, C. M. : Sediment entrainment and suspension in a turbulent tidal flow, Marine Geol., Vol. 18, 1975.

8）馬場洋二・岩井国臣 : 感潮部河道における浮遊物質の移 動特性について, 第 24 回水理講演会論文集, 1980 .

9) Lepetit, J.P. and Davesine, M. : Dynamics of silt in estuary, residual current or flocculation which prevails?, Proc. 17th Coastal Eng. Conf., ASCE, 1980.

10) Harrison, A. J. M. and Owen, M. W. : Siltation of fine sediments in estuaries, Proc. 14th Congress IAHR, Paris, D 1, 1971.

11) Wang, D.P. : Two-dimensional branching salt intrusion model, Proc. ASCE, Vol.109, No. WW 1, 1983.

12）岩佐義朗・井上和也・田中 靖: 河口感潮域の流れ之拡 散の数值シミュレーション, 京都大学防災研究所年報, 第 25 号, B-2, 1982.

13) Stommel, H. and Farmer, H. G. : Abrupt change in width in two-layer open channel flow, J. Marine Research, Vol.11, No.2, 1952.

14）須賀堯三・高橋 晃：河口流出流に関する実測に基づく 考察, 第 24 回海岸工学講演会論文集, 1977.

15）柏村正和・吉田静男：河口二成層の流れの構造解析，第 22 回海岸工学講演会論文集, 1975.

16）福岡捷二・福鴄祐介・守屋祥一・新庄高久：河口密度流 の流動機構と塩水くさびの河口条件, 土木学会論文報告 集, 第 327 号, 1982.

17）柏村正和・吉田静男：河口の flow pattern について, 第 
12 回水理講演会講演集, 1968 。

18）福岡捷二・福島祐介 - 守屋祥一：河口密度流の界面形状 と拡がりに関する実験, 第 35 回年次学術講演会講演概要 集, 第 II 部, 1980.

19) Özoy, E. and Ünluiata, Ü. : Ebb-tidal flow characteristics near inlets, Estuarine, Coastal and Shelf Science, 1982.

20）柏村正和・吉田静男 : 潮汐による河口の flow pattern の 変化, 第 19 回海岸工学講演会論文集, 1972.

21）中村重久：高潮に伴う河口付近の流れについて，日本海 洋学会誌, 第 23 回第 4 号, 1967.

22) Wright, L. D., Thom, B. G. and Higgins, R. J. : Wave influence on river-mouth depositional process, Estuarine and Coastal Marine Science II, 1980.

23) Wright, L. D. and Coleman, J. M. : Mississippi river mouth process; effluent dynamics and morphologic development, J. Geol., Vol. 82, 1974.

24）須賀堯三：非定常河口流出流と内部ジャンプ渦，第 28 回 海岸工学講演会論文集, 1981 .

25）吉田静男：弱混合河口二層流の界面破壊，第 27 回水理講 演会論文集，1983。

26）大西外明・田中総太郎：二成層密度流における多重フロ ント現象の観測とそれに基づく連行量算定法，第 27 回海 岸工学講演会論文集, 1980 .

27) Whitham, G. B. : Linear and Nonlinear Waves, WileyInterscience, 1973.

28) Christoffersen, J. B. : Current depth refraction of dissipative water waves, Ser. Paper No. 30, Inst. Hydrodyn. \& Hydr. Eng., Tech. Univ. Denmark, 1982.

29) Peregrine, D.H. : Interaction of water waves and currents, Advances in Applied Mech., Vol.16, 1976.

30）加藤 始：波と流れとの相互干渉, 1978 年度水工学夏期 研修会講義集, 1978.

31) Jonsson, I. G. and Wang, J. D. : Interaction between waves and currents, Proc. 12th Coastal Eng. Conf., 1970.

32) Jonsson, I. G. and Wang, J. D. : Current-depth refraction of water waves, Series Paper No.18, Inst. Hydrodyn. \& Hydr. Eng., Tech. Univ. Denmark, 1978.

33）浜田徳一・加藤 始：流れの中の有限振幅波の計算, 第 10 回海岸工学講演会講演集, 1963.

34）佐藤道郎：不等流を遡る波の波高変化に関する基礎的研 究, 土木学会論文集, 242 号, 1975.

35）加藤 始：対数分布の吹送流に対する波速の計算，土木 学会論文集, 239 号, 1975.

36) Dalrymple, R.A. : Water waves on a bilinear shear current, Proc. 14th Coastal Eng. Conf., 1974.

37) Jonsson, I. G., Brink-Kjaer, O. and Thomas, G. P. : Wave action and set-down for waves on a shear current, J. Fluid Mech., Vol. 87, 1978.

38) Kemp, P.H. and Simons, R. R. : The interaction between waves and a turbulent current waves propagating with the current, J. Fluid Mech., Vol.116, 1982.
39) Dalrymple, R. A. : Finite amplitude waves on a linear shear current, J. Geophys. Res., Vol.79, 1974.

40）堺 茂樹・佐伯 浩 - 尾崎 晃：一様流を伴う有限振幅 波理論の適用性, 第 30 回海岸工学講演会論文集, 1983.

41）黄 煌輝・郭 金棟：流れの中におけるStokes 波の shoaling について, 第 22 回海岸工学講演会論文集, 1975.

42）土屋義人・安田孝志：一様流を伴う有限振幅波の理論, 第 22 回海岸工学講演会論文集, 1975 .

43) Kjaer, O. B. : Gravity waves on a current, Series Paper 12, Inst. Hydrodyn. \& Hydr. Eng., Tech. Univ. Denmark, 1976.

44) Iwagaki, Y., Sakai, T., Tsuda, T. and Oka, Y. : Wave refraction and wave height variation due to current, Bull. Disas. Prev. Res. Inst., Kyoto Univ., Vol. 27, 1977.

45) Grant, W. D. and Madsen, O.S. : Combined wave and current interaction with a rough bottom, J. Geophys. Res. Vol. 84, 1979.

46) Tanaka, H. and Shuto, N. : Friction coefficient for a wave-current coexistent system, Coastal Eng. in Japan, Vol. 24, 1981.

47）田中 仁・首藤伸夫：波・流れ共存場の抵抗則と境界層 の領域区分, 土木学会論文集, 342 号, 1984.

48) Madsen, O.S. and Grant, W. D. : Sediment transport in the coastal environment, R. M. Parsons Lab., M.I. T., Rep. No. 209, 1976.

49) 金子 新 : A study of sand ripples generated under oscillatory flow, 九州大学学位論文, 1981

50) Shibayama, T. and Horikawa, K. : Laboratory study on sediment transport mechanism due to wave action, 土木学会論文報告集, 296 号, 1980.

51）山下俊彦・沢本正樹・秋山義信・山崎泰助：波動場での 砂粒子の移動確率と掃流砂量に関する研究, 第 30 回海岸 工学講演会論文集, 1983.

52）香取完和・渡辺 晃・堀川清司：シート・フロー状態の 底質移動に関する研究, 第 27 回海岸工学講演会論文集, 1980.

53）山本晃一：河口断面形状について, 第 19 回水理講演会論 文集, 1975 .

54）山本晃一：河口処理論（1）——主に河口砂州を持つ河川 の場合, 土木研究所資料, 第 1394 号, 1978.

55）堀川清司・砂村継夫：千葉県屏風ヶ浦の海岸侵食につい て $(2)$, 第 17 回海岸工学講演会論文集, 1970.

56) Chang, H. H. : Fluvial hydraulics of deltas and alluvial fans, Proc. ASCE, Vol. 108, No. HY 11, 1982.

57) Grijm, W. : Theoretical forms of shorelines, Proc. 7th Coastal Eng. Conf., 1960.

58) Bakker, W. T. and Edelman, T. : The coastline of river-deltas, Proc. 9th Coastal Eng. Conf., 1964.

59) Tsuchiya, Y. and Yasuda, T. : Mathematical models for predicting shoreline change of deltas, Proc. ASCE, J. Waterways, Port, Coastal and Ocean Div. , (投稿中).

60) Komar, P. D. : Computer models of delta growth due to sediment input from rivers and longshore transport, Geol. Soc. American Bull., Vol. 84, 1973. 
61）橋本 宏: 河口部海岸線の変化特性, 土木技術資料, 17-12, 1975.

62）佐藤清一：河口閉塞とその防止策について——神戸川に おける河口処理の一例, 第 2 回海岸工学講演会講演集, 1955.

63）本間 仁・堀川清司・影山正樹・鮮干 澈：相模川河口 について, 第 8 回海岸工学講演会講演集, 1961.

64）野田英明：河口閉塞と漂砂，1974 年度水工学夏期研修会 講義集, B, 1974.

65）野田英明：河口閉塞に関する二，三の実験，京都大学防 災研究所年報, 第 10 号 B, 1967.

66）鮏川 登・浦野光央：河口付近における砂の堆積現象に 関する実験的研究, 土木学会第 27 回年次学術講演会講演 概要集, 1972.

67) O’Brien, M.P. : Equilibrium flow areas of tidal inlets on sandy coasts, Proc. 10th Coastal Eng. Conf., 1966.

68）吉高益男・島田米夫：河口の平衡断面積について, 第 14 回海岸工学講演会講演集, 1970.

69）椹木 亨：河口閉塞にともなう河道内水位の変化につい て, 第 15 回海岸工学講演会講演集, 1968.

70) 山本晃一: 河口の断面特性, 第 23 回海岸工学講演会論文 集, 1976.

71）中村 充・佐々木泰雄：河口滞砂における掃流砂関数の 検討, 第 14 回水理講演会講演集, 1970.

72）青田茂雄・首藤伸夫：河口断面積変化過程の数值モデル, 第 24 回水理講演会論文集, 1980.

73）宇多高明：新しい海浜変形モデルによる河口砂州の変形 予測, 土木学会論文報告集, 322 号, 1982.

74）椹木 亨・小船浩二：河口水位変化に及ぼす導流堤の効 果について，第 16 回海岸工学講演会講演集, 1969.

75）須賀堯三・松村圭二・浜谷武治・高橋 隆：全国河川河 口閉塞資料の検討 (その 2 ), 土木研究所資料, 第 267 号, 1970.

76）豊島 修：海の側から河口を見る, 海岸, Vol.21, 1981.

77）建設省土木研究所：手取川河口処理に関する水理的検討, 土木研究所資料, 第 1069 号, 1975.

78）椹木 亨: 漂砂と海岸侵食, 森北出版, 1982.

79）豊島 修: 河口処理をみる, 海岸, Vol.23, 1983.

80）大和川河口部港湾埋没対策技術研究会 : 大和川河口部港 湾埋没対策調查報告書, 大阪府港湾課, 1982 .

81) Nishimura, J. K. and Lau, L. S. : Structure for automatic opening of closed stream mouths, Shore and Beaches, Vol. 47, No.4, 1979.

82）須賀堯三：感潮河川における塩水くさびの水理に関する 基礎的研究，土木研究所資料，第 1573 号，1979.

83）須賀堯三：河川における塩水くさびと内部渦の特性, 第 23 回水理講演会論文集, 1979.

84）石崎勝義・井戸康雄 - 矢沢聖一：堤内地への塩水侵入の 実態と機構について, 第 36 回建設省技術研究会講演概要, 河川部門, 1982.

85）村岡浩爾: 流れによる底泥浮上と水質との関連, 第 18 回 水理講演会論文集, 1974 .

86）柏谷 衛・村上 健: 河床底泥の成分と酸素吸収速度, 第 26 回土木学会年次学術講演会講演概要集 II, 1971.
87）須賀堯三・山田三郎：河道内波浪遡上と水理実験, 土木 技術資料, Vol.13, No. 12, 1971.

88）富永正照 - 山口高志・須賀堯三・鵜木和夫・高橋 隆： 久慈川河口水理模型実験報告書 ( II ), 土木研究所資料, 第 631 号, 1971 .

89）松村圭二：淀川消波工模型実験報告書（その 2 ), 土木研 究所資料, 第 446 号, 1969 .

90）富永正照 -九津見生哲: 太田川高潮対策模型実験報告書, 第 748 号, 1972.

91）室田 明：水理観測における規模の評価に関する研究報 告書, 土木学会水理委員会, 1971 .

92）建設省河川局：改訂建設省河川砂防技術基準（案), 調查 編, 日本河川協会, 1977.

93）運輸省港湾局：港湾調查指針，日本港湾協会，1971.

94）服部昌太郎：最近の現地観測とその成果について, 1981 年度水工学夏期研修会講義集, B, 1981.

95）土屋義人・吉岡 洋・棚橋輝彦・市川雅史・士子良治： 超音波式流速計による長期潮流観測について, 第 30 回海 岸工学講演会論文集, 1983.

96) Grant, H. L., Stewart, R.W. and Moilliet, A. : Turbulence spectra from a tidal channel, J. Fluid Mech., Vol. 12, 1962.

97）田城徽雄・吉田静男・満沢巨彦：河口二層流における乱 流構造の観測，第 28 回水理講演会論文集， 1984 .

98）佐々木民雄：海浜流系の現地観測, 1978 年度水工学夏期 研修会講義集, B, 1978.

99）田中 仁・首藤伸夫：鮫川河口部の水理現象に関する現 地観測, 第 28 回海岸工学講演会論文集, 1981 .

100）須賀堯三・高橋 晃：河口流出流に関する実測に基づく 考察, 第 24 回海岸工学講演会論文集, 1977.

101）熟見栄一：二層型超音波流速計の測定結果について, 公 害資源研究所報, Vol.4, No.1, 1974 .

102）堀川清司・砂村継夫：可視領域リモートセンシングによ る海岸環境の計測, 第 23 回海岸工学講演会論文集, 1976.

103）宇多高明・橋本 宏：リモートセンシングによる海底地 形・海浜流の同時観測, 第 24 回水理講演会論文集, 1980.

104）上原忠保・岩崎敏夫：小河川感潮部地域における侵入塩 分の挙動に関する研究, 第 27 回水理講演会論文集, 1983.

105）吉田静男 - 谷藤康造 : 天塩川河口二層流と潮汐, 第 28 回 水理講演会論文集, 1984.

106）大谷守正・西條淳夫 -八鈋 功：2 層流界面計の試作と 非定常界面変動の観測, 第 28 回水理講演会論文集, 1984 .

107）柏村正和·吉田静男 : 天塩川の河口密度流, 第 23 回海岸 工学講演会論文集, 1976.

108）吉田静男 : 弱混合二層流の界面破壊, 第 27 回水理講演会 論文集, 1983 .

109）中野 渉・遠藤 浩・八鈋 功：短周期界面波における 非線形現象の発生条件, 第 28 回水理講演会論文集, 1984.

110）吉田静男 - 谷藤康造 - 田城徽雄 - 西田修三 : 弱混合河口 二層流の特性, 第 26 回水理講演会論文集, 1982 .

111）大西外明・須山 哲・村上龍一：ランドサットデータを 導入した本州周辺の河川水拡散状態の研究 $(1)$, 第 28 回水理講演会論文集, 1984 .

(1985.10.4 • 受付) 